\title{
MEASURING THE IMPACT OF SOME ECONOMIC VARIABLES ON PRIVATE INVESTMENT (IRAQ CASE STUDY)
}

\author{
Fahad Mghemish Huzayran ${ }^{\mathrm{a}}$, Ihab Ali Dawood Al-Nawab ${ }^{\mathrm{b}}$, Hebat Allah Mustafa ${ }^{\mathrm{c}^{\star}}$
}

a. Warith Al-Anbiyaa University - College of Administration and Economics, Iraq b. Ministry of Trade - Department of Commercial and Financial Supervision - Holy Karbala Branch, Iraq

c. Warith Al-Anbiyaa University - College of Administration and Economics, Iraq. Hebatallah.Mu@g.uowa.edu.iq

Received date: 07/08/2021, Accepted date: 06/ 10/2021, online publication date: 31/ 12/2021

\begin{abstract}
The topic of the study was chosen based on the importance of investment in general and private investment in particular, and the research started from the hypothesis that there are some macroeconomic variables that have a significant impact on private investment in Iraq, which caused a decrease in the role of the private sector in the economy, For the purpose of proving the hypothesis, the research was divided into two topics, as the first section dealt with the theoretical framework of private investment and its relationship to some economic variables such as inflation, unemployment and gross domestic product, while the second study dealt with the standard aspect to explain the effect of these variables on private investment, and the research reached several conclusions, the most important of which is the proof of the significance of the regression coefficient For the independent variables on private investment through $(t)$ test, as $(t)$ calculated is greater than the tabular for all variables, and the $(F)$ test indicates the statistical significance in the model that the value of $(F)$ calculated is greater than the tabular. As for the recommendations, the most important one is to give the private sector more support, attention and care by expediting the adoption and implementation of legislation and laws that increase the participation of this sector in the economy and make investments.
\end{abstract}

Keyword: private investment, gross domestic product, inflation, unemployment.

JEL Code: E3, P24, E24, E2.

\section{INTRODUCTION}

Investment is of great importance in advancing the national economy in any country in the world, as it is one of the important economic activities that achieve economic and social development and increase capital accumulation. Hence, the importance of

\footnotetext{
^ Corresponding Author
} 
studying private investment as one of the important vital economic issues as it represents a fundamental axis of the economic development process. However, the success of private investment or not depends largely on the macroeconomic variables within the economy, such as inflation, unemployment, gross domestic product, economic diversification and interest rates.

\section{FIRST: THE CONCEPT OF PRIVATE INVESTMENT}

Investment is defined as ((change in the capital stock during a specific period of time)) and investment determines the rate of capital accumulation and is divided into three paragraphs: capital formation, change in stock and real estate investment (Abdel Azim, 2007: 2). It is divided into public investment for the public sector and the last private investment for the private sector. It is widely known that private investment both domestic and foreign - is the main driver of economic growth. For example, a number of countries that have witnessed high growth rates over the course of Private investment in the past two decades is consistently higher than in countries that have not experienced such sustainable economic expansion (UNCTAD, 2010: 8). The weak economic performance is mainly due to the loss of investor confidence, which has led to a slowdown in private investment (Kalim Hyder \& Qazi Masood Ahmed, 2018: 3). It means private investment ((those investments made by individuals or companies (local or foreign), in which activities are subject to the control and direction of the non-governmental unit (private, companies or individuals). In other words, private investment includes all profitable companies that do not own or manage them. (Government) (Ndugbu MO and others, 2019: 68). Or is ((It is the privately owned part of the economy, that is, the part of the free market economy that is made up of companies that are not owned and not run by the government)) (Thabani Nyoni, Wellington G. Bonga, 2017: 38). Private investment is also referred to as ((the addition to the production capacity and human resources of the community, which is carried out by a private company or project, and a private investment project is launched with the aim of basically making a profit within a certain period of time) (Manshi, 2019: 16). Investment spending plays a group of vital roles in the economy, as it is a major component of aggregate demand, and consequently, fluctuations in investment spending lead to stagnation or recovery, and investment is generally defined as ((an expensive behavior today but leads to future profits)) (O'Sullivan Others, 2014: 33). Theories of investment go back to Keynes (1936), who first drew attention to the existence of an independent investment function in the economy. The main feature of Keynesian analysis is the observation that although savings and investment must be identical at a later time, saving and investment decisions are made Generally by different decision makers and there is no reason why ex ante savings should be on par with previous investment. The next stage in the development of investment theory led to the emergence of the accelerator theory, which makes investment a linear proportion of changes in output. In this acceleration model, expectations, profitability and capital costs do not play any role (Asante, 2000: 3). Private investment represents a powerful means for innovation, economic growth and poverty reduction, and countries that have broader and deeper investments in the private sector are showing rapid growth, as it creates more jobs, generates more revenues and increases the income of the poor, so it is very important for the economy to increase its investment in the private sector (Majeed \& Khan, 2008: 2). 
Vol. 5, No. 2 (December 2021); ISSN: 2602-5655

\section{SECOND: FACTORS AFFECTING PRIVATE INVESTMENT}

Private investment is affected by a set of factors that limit its ability to expand and succeed, among which are (ESMAP TECHNICAL PAPER, 2001: 4):

1- The general situation of the country (such as the investment climate and the economic situation).

2- Organizational issues (such as maturity of the regulatory framework, performance incentives, and flexibility).

3- Laws and the legal system (such as compliance with contracts, environmental laws, and arbitration).

4- The state of the target company (for example, level of losses and employee skills).

5- Availability of resources (for example, robustness of the energy sector, power supply).

6- Potential financial performance (for example, returns and their stability, ability to finance).

7- Characteristics of the investing company (for example, consistency with company strategy, synergy with other companies)

Studies indicate that the Gross Domestic Product: Gross Domestic Product is one of the most influencing variables on private investment. Gross domestic product / real GDP / economic growth / real income contributes positively to the development of private investment. Where the gross domestic product contributes to the promotion of private investment, the gross domestic product shows an increase in sales and profits, and this would enhance the expansion of private investment in the economy, as it is assumed that a rise in real GDP per capita leads to an increase in effective demand for goods and services and thus inspires Private investors to increase investment (Batu, 2016: 54)

While others put forward a set of factors and determinants of private investment are (Ali, 2014: 156):

- Direct and indirect taxes, licensing costs, establishment procedures, and the size of the local market.

- The extent to which property rights are respected, contracts is imposed, and tariff and quantitative restrictions imposed on imports, exports, and all kinds of risks.

- The rate of economic growth, inflation, the abundance of infrastructure, information, transparency, labor regulations, the labor market, and the role of trade unions.

- The fluctuation of the prices of stocks, bonds, interest and exchange. There are other factors related to political and legislative security.

Both Paul Samuelson and Nord House believe that the determinants of investment in addition to GDP are costs, as it is the second most important determinant of the level of investment, and costs are the cost of borrowing, and here we mean both the interest rate and taxes. The other element in determining investment is expectations of profit and reliability, that is, expectations monitored by businesses of what the economy may be exposed to from future fluctuations (Samuelson, House, 2006: 487).

There are those who consider public investment spending as another influencing variation in private investment, as the role of public investment is viewed from two sides. On the one hand, public investment, in the form of basic infrastructure, is complementary to private investment and thus promotes the expansion and development of the private sector, and on the other hand, the Public spending is the prerogative of the private sector and thus reduces the amount of money available to them. However, on the other hand, the results were found that support the theory of (crowding out influence) or what is known as (crowding out 
effect), where public investment is inversely related to private investment, and this indicates the existence of competition for resources between the public and private sectors (Batu: 54). The Empirical results indicate that private sector equipment investment is inversely related to government investment spending and is directly related to the current public capital stock, and that investment in equipment and infrastructure is more sensitive than public capital than investment in equipment and infrastructure (Erenburg, 1993). Finally, private investment (domestic and foreign) can enhance employment and productivity, technology transfer and can bring in foreign currencies until reserves are improved. This is if we know that private companies invest more than their size and are more responsive to changes in investment opportunities than public companies (Feleke, 2014: 77).

\section{THIRD: THE RELATIONSHIP OF PRIVATE INVESTMENT WITH THE VARIABLES OF THE STUDY}

\subsection{The relationship of private investment to the gross domestic product}

We explained previously that there is an effect of the gross domestic product on private investment, and that the increase in the size of the gross domestic product is a positive indicator of the increase in the volume of private investment, and it seems that this relationship is reciprocal between both private investment and GDP. As the increase in private investment also leads to a rise in the gross domestic product per capita, as the influx of private investment helps countries produce goods with added value, and with the high demand for commodities, domestic resources are fully used and this leads to an increase in the size of the gross domestic product (Fatima, 2011: 370).

Figure 1: The relationship between investment and gross domestic product

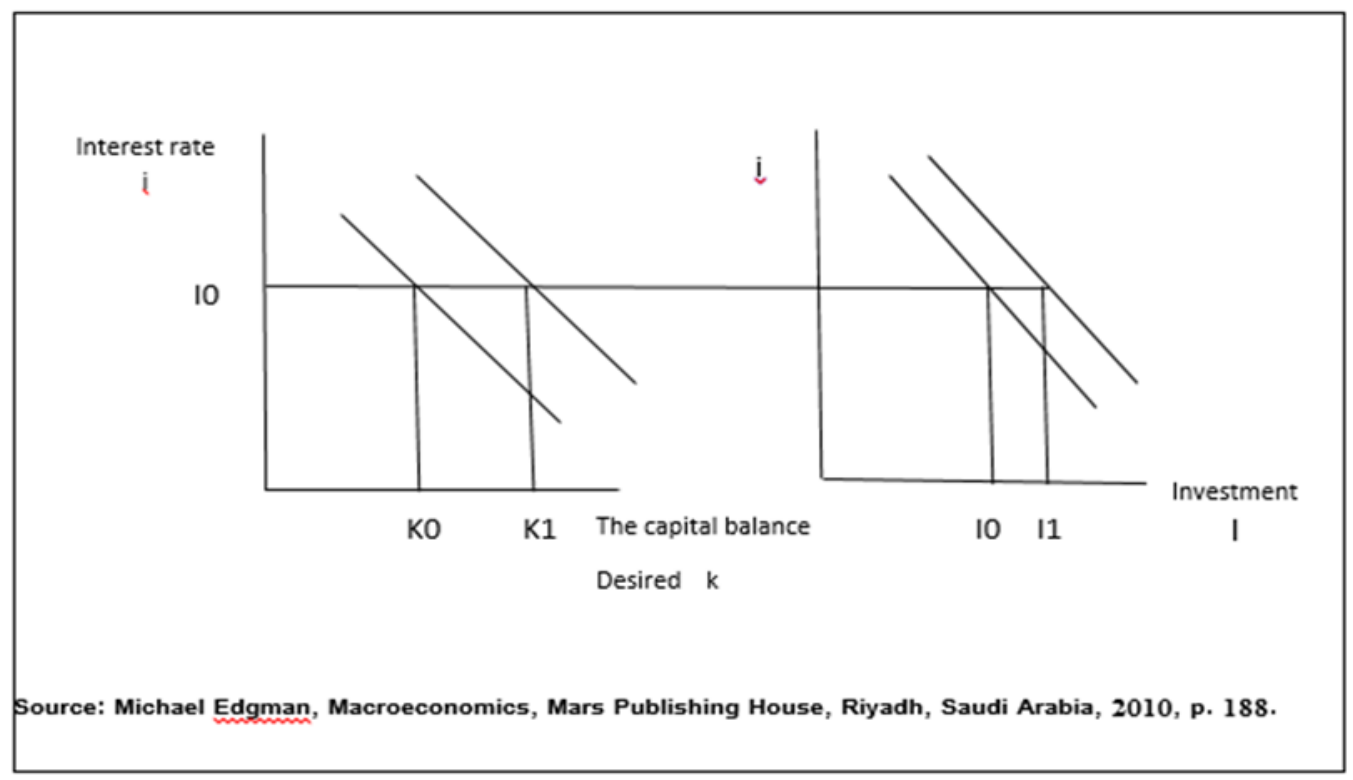

As in the event of a rise in the GDP, the relationship between the interest rate and the desired capital stock changes, as the desired capital stock will increase, so when the GDP increases, the desired capital trend moves to the right (K1), which in turn will be reflected in the shift of the investment curve to the right (I1 ), That is, the relationship of investment to GDP is a direct one (Bedjman, 2010: 187-188).

\subsection{The relationship of private investment to unemployment}

Investment is the main determinant of economic growth, as it greatly boosts output through an increase in the demand for inputs, which in turn will increase employment 
and general welfare as a result of the increase in income received by society (Muammil, 2018: 97). The ILO highlights the importance of private investment to enable the "decent work" agenda, with a focus on how to promote enterprise development and improvements in business, enabling environments can contribute to the right preconditions for companies to employ people on a decent basis. Private investment plays a crucial role in Creating job opportunities to meet employment challenges (Lemma, 2019: 4).

Research indicates that the increase in manpower employment is due to the initial investments made by companies directly, but many economies have unused resources, including capital available for investment but not invested and unemployed workers (Sosa, Audenrode, 2011: 2-4) The increase in private investment can positively improve employment, through increased employment as a direct result of increased investments, as well as creating job opportunities in other sectors as an indirect result of initial investments. The Ghana Gold Mining Company states that for every direct job created in the mine, another 28 jobs were created in the economy (IFC JOBS STUDY NEWSLETTER, 2012: 1).

Private sector investment has also provided about $90 \%$ of employment opportunities in the developing world (including formal and informal jobs), provides vital goods and services, contributes to tax revenue and an effective flow of capital, as it contributes to developing and maintaining infrastructure and services, strengthening and expanding existing businesses. Promote human capital development, to help vulnerable groups especially to participate in the labor market, encourage community development by promoting community businesses, cooperatives, local exchange systems, informal credit, etc. A private sector is essential to promoting SMMEs through supply-side measures (training, provision of space and facilities for commercial activities etc.) and demand-side measures (procurement policy reforms to ensure SMEs access to contracts) (Topic guide, 2016: 17).

And if the economy has surplus capacity, a rise in private investment could also lead to a multiplier effect, as the initial increase in investment increases economic growth and employment, but if companies earn more sales and profits, they are willing to reinvest that in more investment, which means Increasing employability and thus reducing sources of unemployment (Pettinger, 2019).

\subsection{The relationship of private investment to inflation}

Inflation creates uncertainty and thus reduces motivation and delay in investment decision-making, creates a problem in resource allocation and has a negative impact on investment benefits (JAMSHID, TANIA, 2013: 1). Uncertainty about inflation is the most important factor after the product, affecting private investment, and this uncertainty leads to a long-term nominal return of debt accompanied by very high risks, and thus leads to an increase in long-term interest rates, and that uncertainty about inflation leads to future payments. Uncertain ; For example, it can make employers and workers uncertain about future salaries, and it can also make landlords and tenants anxious about future expectations (Pahlavani, Bashiri, 2013: 62-63).

Some economic opinions indicate that increased uncertainty leads to an increase in investment as commercial capital is an increasing function of prices and when the price variation increases, the expected return also increases, and higher prices when the markets are competitive will lead to an increase in investment. While others see that the relationship is negative between the two parties, as it was found, for example, that the relationship between corporate investment and inflation in a sample of 21 countries in the Organization for Economic Cooperation and Development over the 
period from 1960-2005, there is a large and strong negative relationship and that the relationship is not The linearity between inflation and output growth comes from the non-linearity between inflation and investment, and this is what the central bank may exploit in periods of slowdown by prolonging the economic recovery period (Abu Asab, Al-Tarawneh, 2018: 114)

In the case of private investments in which delay is not possible in a way that allows projects to collect new information about prices and other market conditions before making the investment. In such a case, the standard rule for investment decisions, which states that a company should invest in a project when the present value of the expected net cash flow exceeds its cost, will not be optimal, because the increasing uncertainty makes companies more reluctant to invest (Fischer, 2013: 5-6).

The effect of inflation on investment depends on the type of investment, for investments with a specified annual return, such as ordinary bonds or bank certificates of deposit, inflation can hurt performance - since interest payments will be the same every year, and this can reduce profits. If someone receives a payment of $\$ 100 \mathrm{a}$ year, for example, that payment will be smaller and smaller each year due to inflation.

As for stocks, inflation could have a mixed effect. Inflation is usually higher when the economy is strong. Firms may sell more, and firms will also pay more in wages and raw materials, hurting their value. Whether inflation helps or hurts stocks depends on the performance of the company behind it. Finally, there are some investments that are rated for inflation risk, which earn more when inflation rises and less when inflation lowers (Western \& Southern Financial Group, Inc: 2020).

\section{FOURTH: PRESENTATION AND ANALYSIS OF THE RESULTS OF THE STANDARD MODEL}

In order to verify the validity of the research hypothesis or not, the EViews 9 statistical program will be used to analyze the impact on GDP, unemployment rates and inflation rates on private investment. The analysis includes the following variables:

1 - IP variable private investment

2- GDP variable

3- Unemployment rate variable UM

4- Variable inflation rate I.

The data of these variables have been used for a time series from 1990-2018, and the data will be analyzed according to the VAR model as well as the causation approach to indicate the type of relationship between the variables, and according to the VAR model, the variables of GDP, unemployment rate and inflation rate are internal variables with a certain time lag, and the relationship can be described. According to the formula:

$\mathrm{IP}=\mathrm{BO}+\mathrm{B} 1 \mathrm{GDP}+\mathrm{B} 2 \mathrm{UM}+\mathrm{B} 3 \mathrm{I}$

\section{1 - Test Stationary stability variables}

The first step should be to test the stability of the model variables and determine the rank of the joint integration of the time series and see if the variables are stable or not. This is done by applying the unit root test to the extended ADF. After the extended root unit (ADF) test, Table (1). 
Vol. 5, No. 2 (December 2021); ISSN: 2602-5655

Table 1: Expanded Dicky Fuller test for unit root

\begin{tabular}{cclcc}
\hline Variable & \multicolumn{2}{c}{ Level } & \multicolumn{2}{c}{ First deference } \\
\cline { 2 - 5 } & $\begin{array}{c}\text { ADF } \\
\text { Stability }\end{array}$ & Result & ADF & Result \\
& $* 5.721613-$ & Stationary & & \\
\hline IP & $* 3.669836-$ & Stationary & & \\
\hline GDP & $\mathbf{2 . 9 8 7 0 0 2}-$ & Non & $* 5.774489-$ & Stationary \\
\hline UM & $* 3.721077-$ & stationary & & \\
\hline$I$ &
\end{tabular}

Source: prepared by researchers depending on the outputs of the standard program

* Morality at the level of 5\%

We note through the table that all the variables were stable at the level and at a level of significance (5\%) except for the unemployment variable, which was stabilized by the first difference, and accordingly, the variables are complementary (cointegration) of the first degree (1) with the existence of a decisive and general trends.

\subsection{Co-integration test}

It is noted that joint integration shows the long-term equilibrium relationship between the variables. Joint integration will be tested in the Johansson method. Since the analysis contains four internal variables, if these variables are integrated together, there are at least three common integration paths. The joint integration test of the model variables was conducted and the results were shown in Table (2).

Table 2: Johansson Combined Integration Test

\begin{tabular}{lll}
\hline The null & Alternative & Statistic Value \\
hypothesis & Hypothesis &
\end{tabular}

Critical Value

\begin{tabular}{lccc}
\hline \multicolumn{3}{c}{ test Trace } \\
\hline$r=0$ & $r>1$ & $102.3340 *$ & 63.87610 \\
$r \leq 1$ & $r>2$ & $55.86752 *$ & 42.91525 \\
\hline$r=0$ & & test Maximum & \\
\hline$r=1$ & $r=1$ & $* 46.46651$ & 32.11832 \\
& $r=2$ & & 25.82321 \\
\hline
\end{tabular}

* Meaning at a significant level 5\%

Source: researcher's preparation

Note from Table (2) the results of the Johanson test indicate that there are two cointegration paths according to the Trace test, and then reject the null hypothesis that there is no common integration at a significant level (5\%). Johansson's maximum value test Indicates the presence of vectors at a significant level (5\%). Which confirms the existence of a long-term balance between the variables of research and this means the possibility of the existence of false regression as well as the results indicate a causal relationship between these variables

\subsection{Granger Causality Test}


The test is used to determine the direction of causation between the study variables. This test shows the causal direction whether it is one-way or two-way, or that both variables are independent. After the test, the results were as shown in Table 3:

Table 3: Cranger's Causality Test

Pairwise Granger Causality Tests

Date: 10/06/2020 Time: 19:21

Sample: $1990-2018$

\begin{tabular}{ccclc}
\hline & & & & Lags: 1 \\
\hline Prob & F-Statistic & Obs & Null Hypothesis: & \\
\hline 0.1364 & 2.36787 & $\mathbf{2 8}$ & LOG GDP & LOG GDP \\
\hline 0.7282 & 0.12352 & $\mathbf{2 8}$ & LOGIP & LOGIP \\
\hline 0.9053 & 0.01445 & $\mathbf{2 8}$ & LOGUM & LOGUM \\
\hline 1. E-07 & 52.9183 & $\mathbf{2 8}$ & LOGIP & LOGIP \\
\hline 0.0235 & 5.81835 & $\mathbf{2 8}$ & LOGI & LOGIP \\
\hline 0.1406 & 2.31627 & $\mathbf{2 8}$ & LOGGDP & LOGUM \\
\hline 0.8485 & 0.03724 & $\mathbf{2 8}$ & LOGUM & LOGGDP \\
\hline 0.6249 & 0.24506 & $\mathbf{2 8}$ & LOGGDP & LOGI \\
\hline 0.1641 & 2.05524 & $\mathbf{2 8}$ & LOGI & LOGGDP \\
\hline 0.5527 & 0.36226 & $\mathbf{2 8}$ & LOGUM & LOGI \\
\hline 0.4099 & 0.70243 & $\mathbf{2 8}$ & LOGIM & LOGU \\
\hline
\end{tabular}

Source: Prepared by the researcher based on the outputs of the statistical program

And the conclusion of the test of causality to Kranger is as follows:

- There is a one-way causal relationship between LOGGDP and LOGIP, meaning that changes in GDP lead to changes in private investment.

- There is no causal relationship between LOGUM and LOGIP, meaning that changes in private investment do not affect unemployment rates and vice versa.

- There is a two-way causal relationship between LOGIP and LOGI, meaning that previous changes in private investment lead to changes in inflation rates and vice versa

- There is no causal relationship between LOGGDP and LOGUM, meaning that changes in GDP do not affect unemployment rates and vice versa.

- There is no causal relationship between LOGGDP and LOGI, meaning that changes in GDP do not lead to a change in inflation rates and vice versa

- There is no causal relationship between LOGUM and LOGI, meaning that changes in unemployment rates do not affect inflation rates and vice versa. 
We conclude from the foregoing that some of the variables have relations between them in one direction and some of them have an independent relationship between them.

5.4. Analysis of the results of the VAR (Vector Autoregression Estimates)

Before analyzing the VAR model for model variables, the number of optimal delay times for these variables should be known. After the test, the results were as shown in Table (4). The optimum delay times based on the AIC standard, the SCWS and the Hanan-Quinn standard are determined mainly as the delay duration that carries the lowest value is chosen for these criteria:

Table 4: shows the number of delays or losses for the VAR model of the search variables

\begin{tabular}{ccccccc}
\hline Lag & LogL & LR & FPE & AIC & SC & HQ \\
\hline 0 & -562.2372 & NA & $4.32 \mathrm{e}+12$ & 40.44552 & 40.63583 & 40.50370 \\
1 & -525.4621 & 60.4162 & $9.95 \mathrm{e}+1$ & 38.9615 & 39.9131 & 39.2524 \\
& & $8^{*}$ & $1^{*}$ & $8^{*}$ & $5^{*}$ & $8^{*}$ \\
\hline
\end{tabular}

* Indicates the optimal number of delays or delays, and all tests at a significant level $(5 \%)$.

LR: LR test.

FPE: Final Predictive Error.

AIC: Standard Akek.

SC: Standard Squares.

HQ: Standard Hanan Quinn.

From the table above we conclude that the number of deceleration times is one period based on the AIC and SC Schwarz criteria. The defaults of the variables were tested based on the above indicators which have the lowest value.

Figure 2: shows the stability of data for the search variables Inverse Roots of AR Characteristic Polynomial

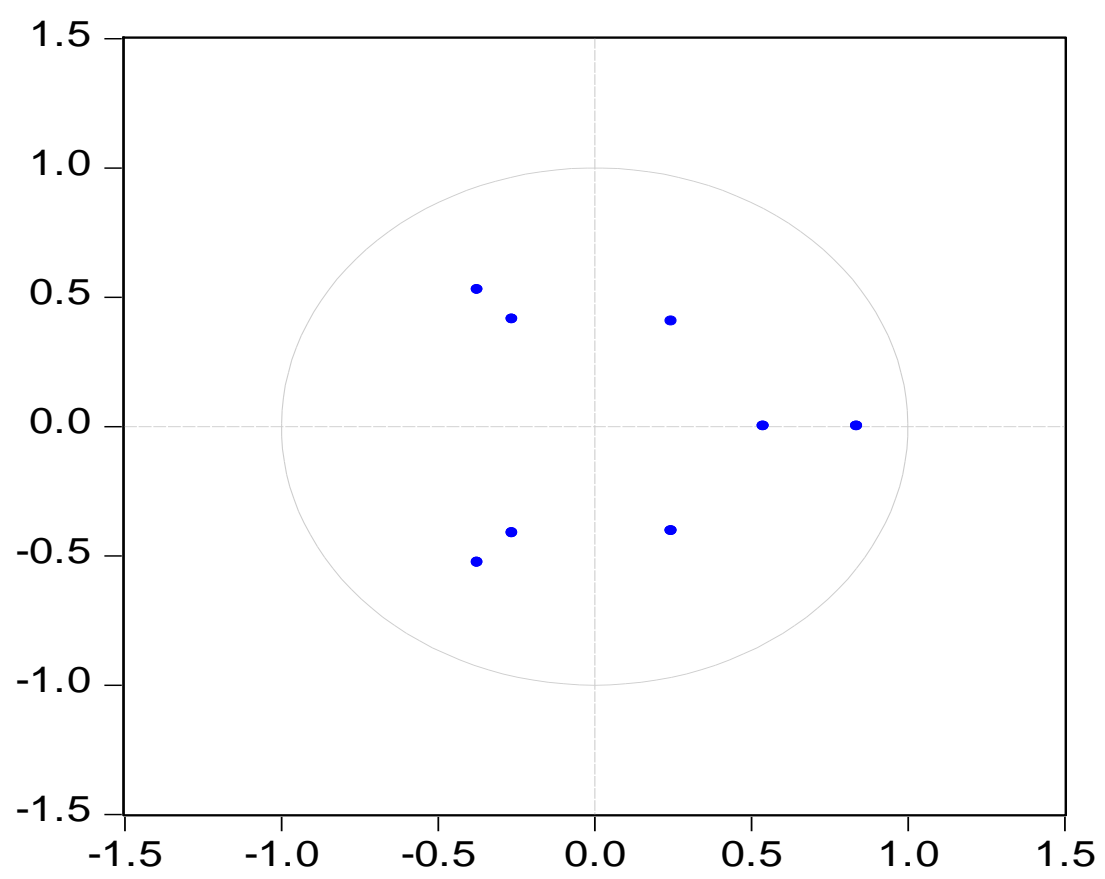


Where we notice from the figure that the coefficients are smaller than the one and all the roots lie within the unit circle, which means that the model is free from the problem of self-correlation or the instability of variance.

Figure 1: Residual oscillation

IP Residuals

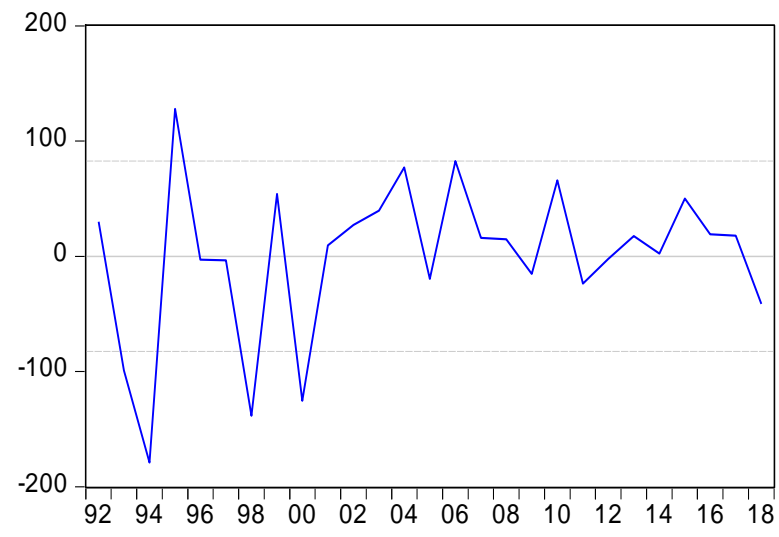

UM Residuals

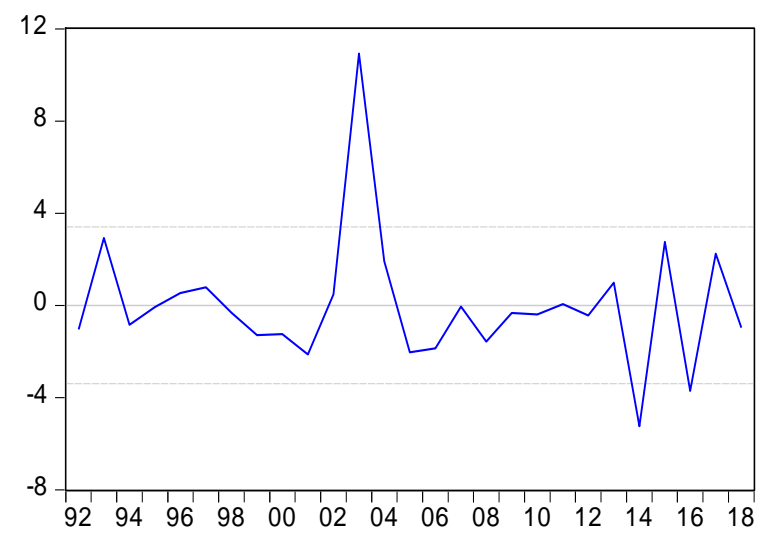

GDP Residuals

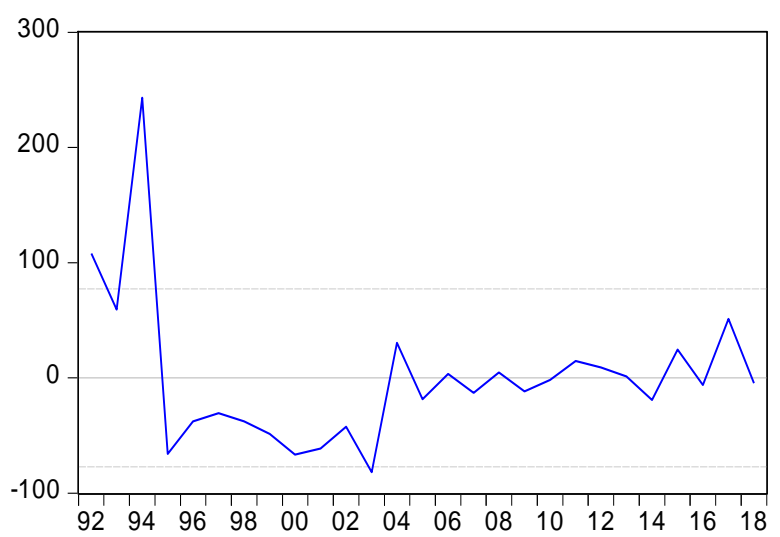

I Residuals

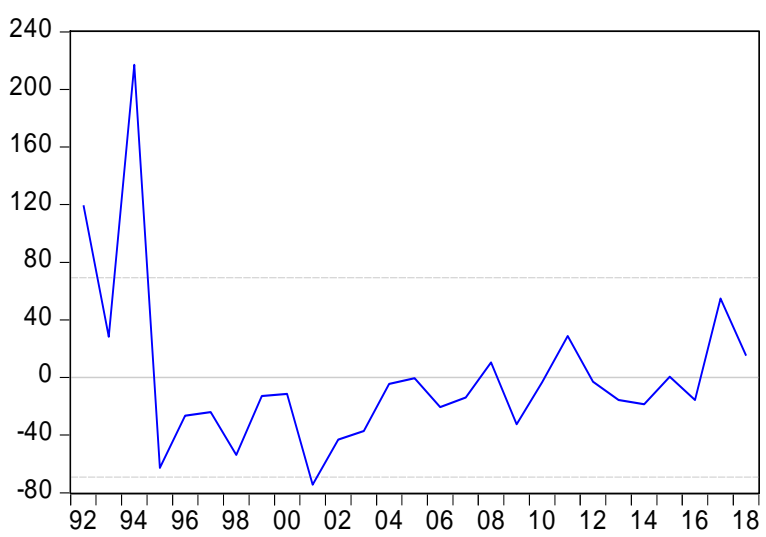

Table 5: Results of VAR model analysis

\begin{tabular}{|c|c|c|c|}
\hline $\begin{array}{c}144.5722 \\
(86.9199)\end{array}$ & $\bar{C}$ & $\begin{array}{l}\text { LOGIP } \\
-0.151627\end{array}$ & $\begin{array}{l}\text { المتغير ات } \\
\text { LOGIP(-1) }\end{array}$ \\
\hline [ 1.66328$]$ & & $(0.21202)$ & \\
\hline 0.810032 & R-squared & {$[-0.71516]$} & \\
\hline 0.725602 & $\begin{array}{l}\text { Adj. } \\
\text { squared }\end{array}$ & 1.131790 & $\begin{array}{l}\text { LOGMGD } \\
\mathrm{P}(-1)\end{array}$ \\
\hline 123310.3 & $\underset{\text { resids }}{\text { Sum }}$ sq. & $(0.45675)$ & \\
\hline 82.76818 & $\begin{array}{l}\text { S.E. } \\
\text { equation }\end{array}$ & [ 2.47790] & \\
\hline 9.594088 & F-statistic & 2.549119 & $\begin{array}{l}\text { LOGUM(- } \\
\text { 1) }\end{array}$ \\
\hline-152.0707 & $\begin{array}{l}\text { Log } \\
\text { likelihood }\end{array}$ & (5.44409) & \\
\hline 11.93117 & $\begin{array}{l}\text { Akaike } \\
\text { AIC }\end{array}$ & [ 0.46824$]$ & \\
\hline 12.36311 & Schwarz & 0.895454 & LOGI(-1) \\
\hline
\end{tabular}


Vol. 5, No. 2 (December 2021); ISSN: 2602-5655

\begin{tabular}{lll}
\hline 78.55540 & $\begin{array}{l}\text { SC } \\
\text { Mean } \\
\text { dependent }\end{array}$ & $(0.46581)$ \\
158.0056 & $\begin{array}{l}\text { S.D. } \\
\text { dependent }\end{array}$ & {$[1.92237]$} \\
\hline
\end{tabular}

\subsection{Estimating the function of study indicators in Iraq}

To estimate the impact models of GDP, unemployment and inflation as independent variables in private investment as a dependent variable for the period (1990-2018), the following is found:

$$
\begin{aligned}
& \mathrm{IP}=-1.3+0.7 \mathrm{GDP}+5.2 \mathrm{UM}+2.86 \mathrm{I} \\
& (0.00) \quad(28.8) \quad(1.71) \quad(2.57) \\
& \mathrm{R} 2=0.98 \quad \mathrm{~F}=58.1 \quad \mathrm{DW}=1.85
\end{aligned}
$$

We note through the model that the independent variables have a positive relationship with the dependent variable, government spending, which means that a rise in the independent variables leads to a rise in the value of the dependent variable.

- The (t) test: The t-test indicated that the regression coefficient is significant for all variables on private investment because the value (t) calculated in the model was for GDP (28.8), for the unemployment rate was (1.71) and for the inflation rate was (2.57), which are all greater than Its tabular value of (1.70).

- The determination coefficient test R2: According to the determination factor, the independent variables affect $98 \%$ of the dependent variable, and the remainder with an amount of $2 \%$ due to a number of other factors not included in the model.

- F-test: The F-test indicates the statistical significance of the model, that the calculated F value of (58.1) is greater than its tabular value of (2.69).

- D.W test: the model did not suffer from a self-correlation problem because the value of D.W lies in the acceptance region of (1.85).

\section{CONCLUSION}

It is evident through Ducky Fuller's extended test that the time series of variables were stable at the level except for the unemployment variable, which stabilized by the first difference at a significant level (5\%), The results of the study indicate the existence of a positive relationship between private investment and independent variables in Iraq during the study period ,The significance of the regression coefficient for the independent variables on private investment was proven through the (t) test, as the $(\mathrm{t})$ calculated was greater than the tabular for all variables, It was found through the (R2) test of the determination coefficient that the independent variables in the study affect a percentage of (98\%) in the dependent variable, while the remainder (3\%) is due to a number of factors not included in the model, The (F) test indicates a statistical significance in the model that the calculated value of $(F)$ is greater than the tabular.

\section{REFERENCES}

Ahmad Buraihi Ali. (2014). Foreign Investment, Growth and Stability Policies. Iraq. Dar Al Kutub.

O'Sullivan et al. (2014). Macroeconomics - Fundamental Principles, Applications, and Tools. Lebanon. Lebanon Library Publishers. 
Samuelson, P., \& Nordhouse, V. (2009). Economics: a textbook.

Adel Abdul-Azim. (2007). Investment Economics: Theories and Determinants. The Arab Planning Institute. The Development Bridge Journal, (67).

Faten Abdel Awal Manshe. (2019). Arab Investments as an Entrance to Economic Integration. Saudi Arabia. Professional Management Expertise Center.

Michael Abdman. (2010). Macroeconomics. Saudi Arabia. Mars Publishing House.

Alberto F. Lemma. (2019). Impacts of private investment on sustainable development in developing countries: session note on on Jobs - direct and indirect impacts on job creation and decent work.

Sosa, D. W., \& Van Audenrode, M. (2011). Private sector investment and employment impacts of reassigning spectrum to mobile broadband in the United States. Boston, et al.: Analysis Group. static1. squarespace. com/static/50d3c930e4b040 d796f7a87a, 51154415, 13.

Securities, P. (2001). Key Factors for Private Sector Investment in Power Distribution.

Feleke, E. (2014). The Role of Private Investment to the Economic Growth of Ethiopia.

Fatima, G. (2011). Testing Relationship of Private Investment and GDP with Fiscal Deficit. In International Conference on Financial Management and Economics. IPEDR (Vol. 11, pp. 367-372).

Fischer, G. (2013). Investment choice and inflation uncertainty.

Michelitsch, R. (2012). Private sector matters for job creation. IFC jobs study newsletter, 1(71312), 1-4.

Hyder, K., \& Ahmed, Q. M. (2003). Why private investment in Pakistan has collapsed and how it can be restored.

Pahlavani, M., \& Bashiri, S. (2013). Dynamic relationship between inflation uncertainty and private investment in Iran: an application of VAR-GARCH-M model.

Majeed, M. T., \& Khan, S. (2008). The determinants of private investment and the relationship between public and private investment in Pakistan.

Batu, M. M. (2016). Determinants of private investment: A systematic review. International Journal of Economics, Finance and Management Sciences, 4(2), 52-56.

Ndugbu, M. O., Osuka, B. O., \& Duruechi, A. H. (2018). Public Sector Investments and Human Capital Development in Nigeria: 1981-2016. IIARD International Journal of Economics and Business Management, 4(2), 33-50. 
Vol. 5, No. 2 (December 2021); ISSN: 2602-5655

Asab, N. A., \& Al-Tarawneh, A. (2018). The Impact of Inflation on the Investment: The Non-Linear Nexus and Inflation Threshold in Jordan. Modern Applied Science, 12(12), 1913-1844.

Pajooyan, J., \& Khosravi, T. (2012). The effect of inflation on private investment. Journal of Investment Knowledge, 118-1, (زمستان 1391).

Erenburg, S. J. (1993). The relationship between public and private investment. The Jerome Levy Economics Institute Working Paper, (85).

Muammil, S. (2018). The effect of government expenditure and private investment on work opportunities and unemployment rate in Indonesia. Journal of Agricultural and Socio-Economic Sciences, 4(7), 92-100.

Pettinger, T. (2017). Investment and economic growth. Economics Help, 6.

Bonga, W. G., \& Nyoni, T. (2017). An empirical analysis of the determinants of private investment in Zimbabwe. Dynamic Research Journals' Journal of Economics \& Finance (DRJ-JEF), 2(4), 38-54.

The Impact of Inflation on Your Savings \& Investments. (2020). Western \& Southern Financial Group, Inc.

Muggah, R. (2016). Urban governance in fragile cities. GSDRC Professional Development Reading Pack, 46.

UNCTAD. (2010). Partnering public and private investment for development.

Asante, Y. (2000). Determinants of Private Investment Behaviour, AERC Research Paper No. 100. Nairobi: AERC. 